\title{
Endangering Residents in Shipitull Village by Landslide at the Surface Mining in South West Sibovc
}

Hysen Ahmeti ${ }^{* *}$ and Vehbi Duraku

${ }^{1}$ Department of Civil Engineering, University for Business and Technology, Prishtina, Kosovo

${ }^{2}$ Water Services Regulatory Authority, Prishtina, Kosovo

\begin{abstract}
Facing the problem of the expropriation of the Shipitull village and the non-advancement of mining activity in the direction of the frontal work for the removal of the clay overburden for the use of coal, geo-mechanical drilling was performed to determine the most accurate physical-mechanical parameters to calculate the height of the partial and generals slopes with the safety factor Fs $>1.2$, to create optimum conditions for the use of the detected coal reserves of 15 million tons of coal with the general $18^{\circ}$ degree angle with safety factors Fs $\geq 1.27$ according to the geotechnical standards. As the basis for calculating the slopes were taken physical-mechanical drilling parameters that were realized in 2015-2017, the tests were performed in the geotechnical laboratory at the INKOS Institute which is licensed to ISO 9001/2015 according to geotechnical standards. Based on the obtained results, statistical processing was performed for the classified parameters (physical) and the mechanical parameters obtained with the triangle test, the direct test and the tensile test. By comparing the physicochemical parameters based on the drilling of 2015 and 2017, there is change of values of angle $\phi^{0}$ and cohesion C in the lithological layers due to the presence of moisture. The calculations were carried out with Slide v6 and Geo5 Fine software. Two methods were used during calculation: Circular and Polynomial methods for partial angle of height $(h)=30 \mathrm{~m}$ and angle $(\alpha)=48^{\circ}$ with the safety factor $F_{s}<1$ and for a general angle of height $(h)=55 \mathrm{~m}$ with angle $(\alpha)=13^{\circ}$ with current useable reserves of 6.8 million tons of coal having Safety factor $F s \geq 1.27$.
\end{abstract}

Keywords: Landslide; Evacuation of inhabitants; Security factor

\section{Introduction}

The area where research for the removal of coal coverings has been conducted and the possibilities for coal exploitation consist of a surface area of $4 \mathrm{~km}^{2}$. During the research of the area it is noticed that there is a part of the clay (heterogeneous) material folded in previous years, but this has been confirmed even during the mapping of drilling and geo-mechanical analyzes that shows problems in the slope demolition by endangering personnel and technological equipment. Due to the change of the parameters, statistical processing of the physical and mechanical parameters with the safety factor permissible according to the geotechnical standards was done to preserve the stability of the mine and at the same time the Shipitull village, where the importance and purpose of this work was the use of coal without risking the inhabitants of the village.

The slope study is mainly dependent on the processes of soil formation from the physical-mechanical parameters of the geological layers of that area, from the economic aspect they have a high cost but with a great importance for accurate information of the geo-mechanical parameters to take measures for the prevention of landslides that could destroy residential homes, such as our case in the Surface Mine in the Southwest of Sibovc.

Based on the factual situation in the field also based on the map of the situation in Figure 1 [1], two Geological-Geophysical profiles have been drawn to verify the actual state from the point of view of the Geotechnical security.

Since the mine is currently active where the coal exploitation for the supply of power plants Kosovo A and Kosova B are based on the profile according to the Figure 2 [1] general coal reserves for the current situation are about 15 million tons of coal, only 6.8 million tons of coal can be used based on the safety factor, as shown in Figure 3 [1] with the height $h=55 \mathrm{~m}$ and the angle $\alpha=13^{\circ}$ with the safety factor Fs $>1.2$ without endangering the inhabitants of the village Shipitull. While the remaining reserves of 6.2 million tons of coal can be exploited only when the expropriation of the Shipitull village is done based on the low, then the mining activity in the village is started, creating technological conditions for operations, each time preserving the factor safety according to the geotechnical criteria according to the Table 1 [2].

\section{Materials and Methods}

\section{Geology}

The geological evaluation and interpretation is carried out within the existing license area according to the map of the situation as shown below in Figure 1.

The Kosovo Basin and the surrounding areas are built by the crystalline rock of Paleozoic and Mesozoic. The location where the basin is located consists of the layer of Upper Cretaceous, which is covered in an irregular manner with tertiary clay, in which the coal is attached. To simplify, the sediments on which coal relies it can be separated from the floor to the ceiling by a ranking such as green clay, coal formation, gray clay and yellow clay as shown in Figure 4.

Within the mining activity, the drilling network is $250 \mathrm{~m} \times 250 \mathrm{~m}$ but in that area, during the technological operations in the field, we encountered clay layers and as a result of this phenomenon, the drilling network was carried out at a distance of $100 \mathrm{~m} \times 100 \mathrm{~m}$.

The western border of Sibovc requires special attention due to the complicated fault structure. The Sibovc Southwest area has an altitude of 630 meters, while the northern one in the direction of Shipitull village at

*Corresponding author: Hysen Ahmeti, Department of Civil Engineering, University for Business and Technology in Prishtina, Kosovo, Tel: +381 38 541400; E-mail: hysenahmeti68@hotmail.com

Received May 04, 2017; Accepted June 12, 2018; Published June 15, 2018

Citation: Ahmeti H, Duraku V (2018) Endangering Residents in Shipitull Village by Landslide at the Surface Mining in South West Sibovc. J Civil Environ Eng 8: 315 doi: 10.4172/2165-784X.1000315

Copyright: @ 2018 Ahmeti $\mathrm{H}$, et al. This is an open-access article distributed under the terms of the Creative Commons Attribution License, which permits unrestricted use, distribution, and reproduction in any medium, provided the original author and source are credited. 


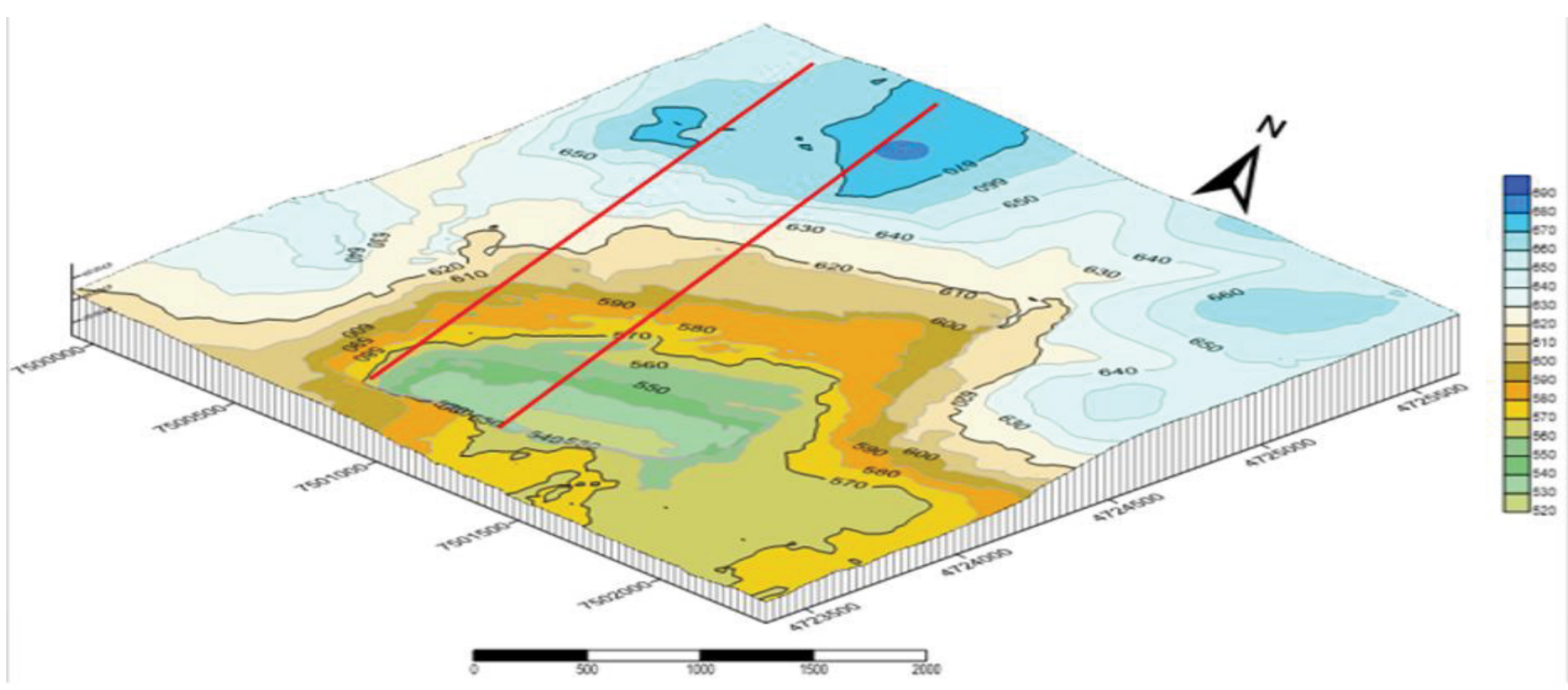

Figure 1: Situation map with position of profiles.

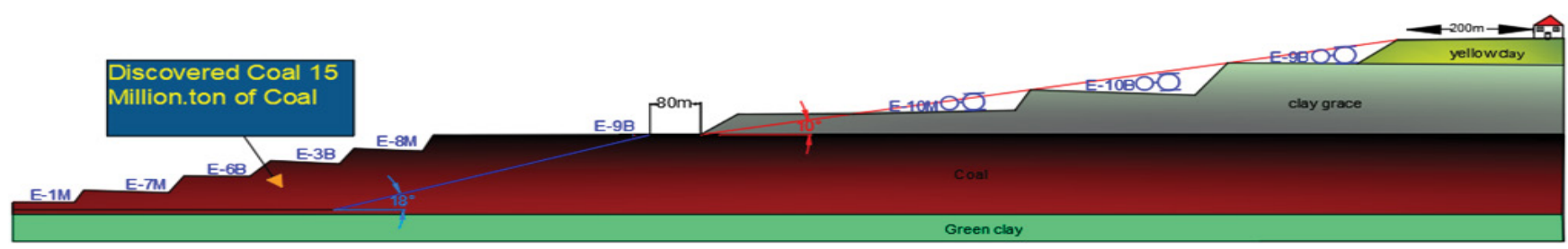

Figure 2: Geologic - Geomechanic profile with the discovered coal reserves of 15 million tons with general angle of $18^{\circ}$.

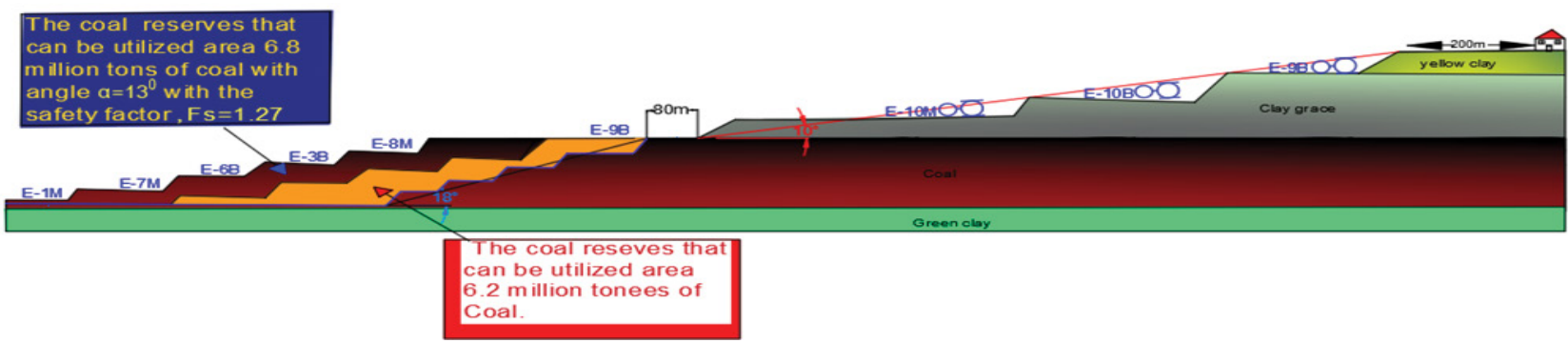

Figure 3: Geo-mechanic profile with exploitable coal reserves of 6.8 million tones with general angle $13^{\circ}$ and $\mathrm{Fs}=1.27$.

\begin{tabular}{|c|c|}
\hline Types of slopes & Security factor $(\mathbf{F s})$ \\
\hline Slopes of working rates & $\geq 1.05-1.10$ \\
\hline Partial slopes & $\geq 1.20$ \\
\hline General working slopes & $\geq 1.20$ \\
\hline Final general slopes & $\geq 1.30$ \\
\hline Slopes near to the capital objects & $\geq 1.40$ \\
\hline
\end{tabular}

Table 1: Geotechnical criteria for the security factor Fs [1].

(front of work) has an altitude of $678 \mathrm{~m}$ and in the direction of Northeast up to $666 \mathrm{~m}$. The slope of these hills has angles from $10^{\circ}$ to $4^{\circ}$ degrees with a general decline in the southeast direction to the southwest. The average thickness of the coal layer is $59.5 \mathrm{~m}$ (maximum $93.1 \mathrm{~m}$ ).

The caloric value ranges from 5,850 to $10,300 \mathrm{~kJ} / \mathrm{kg}$, while the geological average is calculated at $8,830 \mathrm{~kJ} / \mathrm{kg}$ (calculated with
$45 \%$ moisture). Taking into account the possibility of water interconnection and the high proportion of water, the calorific value in landfills is estimated at $7,500 \mathrm{~kJ} / \mathrm{kg}$. Coal overburden thickness varies from 50 to $125 \mathrm{~m}$ with the lowest values near the northern boundary of the existing mines. Technological developments should be based on the geotechnical security of surface mining in southwest Sibovc, which should be treated as a basic process of data according to the development scheme (Figure 5).

\section{Geomechanics}

Depending on the conditions of general knowledge (geological, hydrological, physical-mechanical parameters and technological parameters) to be incorporated in the geo-mechanical model, are given also the geo-technical criteria for the safety factor (Fs).

Based on the mentioned criteria for geotechnical security, taking into account the economic aspect in the implementation of technological 


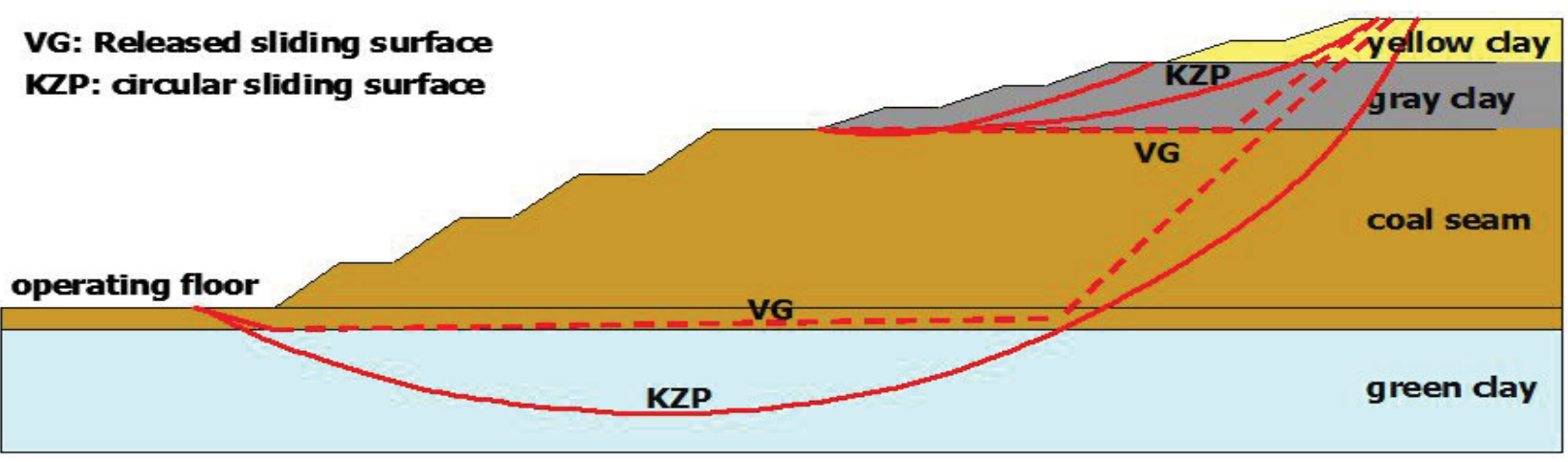

Figure 4: Scenarios of slides that should be analysed.

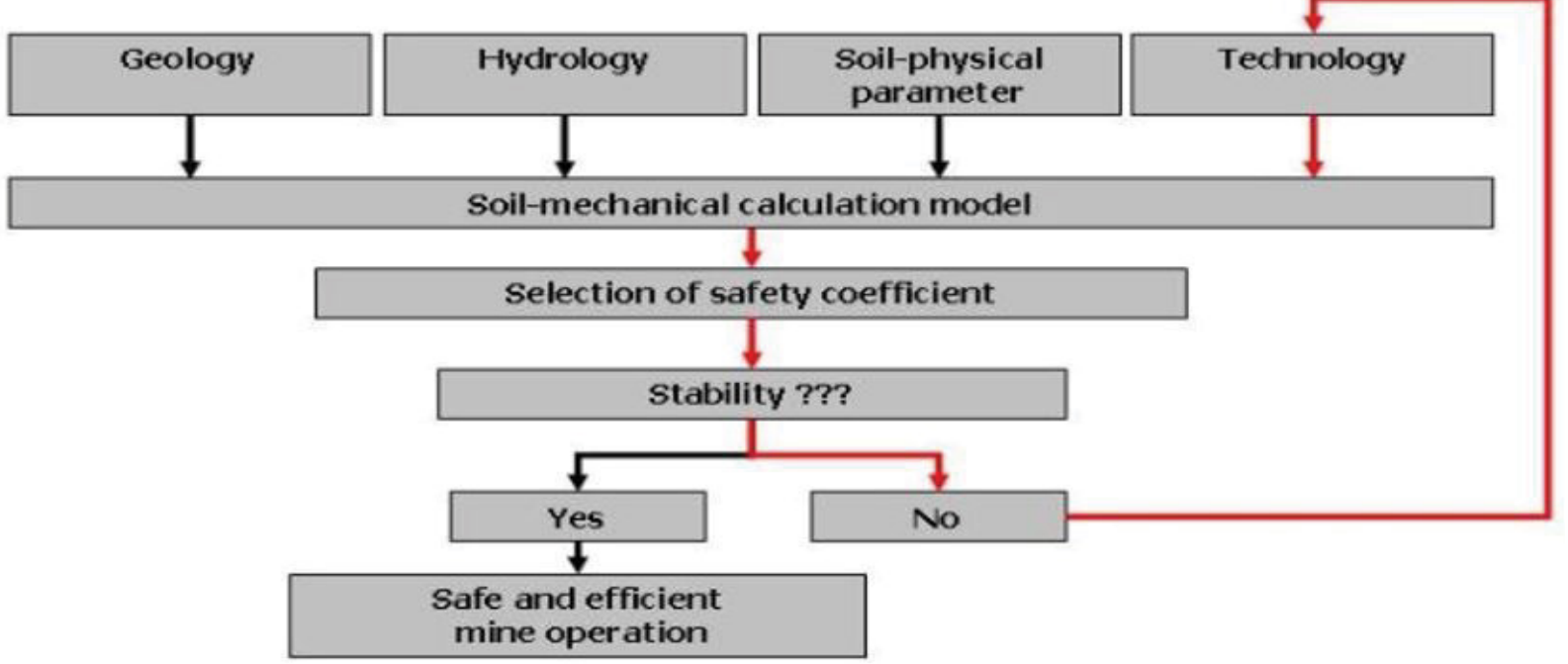

Figure 5: Repeating process for the development of geotechnical security in the surface mine.

operations without consequences, the criteria for the safety factor is given in Table 1.

\section{Geographical position}

The geographical location of the surface mine is located between the city of Obiliç and Pristina, which lies in the sixth kilometer of Pristina towards Obiliç, as shown in the Figures 6 and 7.

\section{Geo-mechanical analysis}

For the determination of the physical-mechanical parameters of the lithological layers in the Surface Mine, geological surveys have been carried out, in which case the following laboratory analyzes were undertaken as follows [3]:
a) Natural humidity $\mathrm{W}[\%]$
b) Weight volume $\gamma\left[\mathrm{kN} / \mathrm{m}^{3}\right]$
c) Specific weight $\mathrm{Gs}\left[\mathrm{kN} / \mathrm{m}^{3}\right]$.
d) Granulometric composition
e) Atterberg's boundaries in consistency
f) Porosity (n) and porosity coefficient (e)

g) Internal friction angle $(\varphi)$ and cohesion (C)

- Direct shear test

- Triaxial test end

- Ring shear test

Processing of statistic classification parameters: Processing of statistical classification parameters is done by calculating:

Average arithmetic value

$\bar{X}=\frac{\sum X i}{n}$

Where: $\mathrm{n}$ - number of samples

$\mathrm{Xi}$ - the characteristic value of a test

Standard deviation

$\sigma=\sqrt{\frac{\sum(X i-\bar{X})^{2}}{n-1}}$

Coefficient of variation

$$
V=\frac{\sigma}{\bar{X}} \times 100 \%
$$




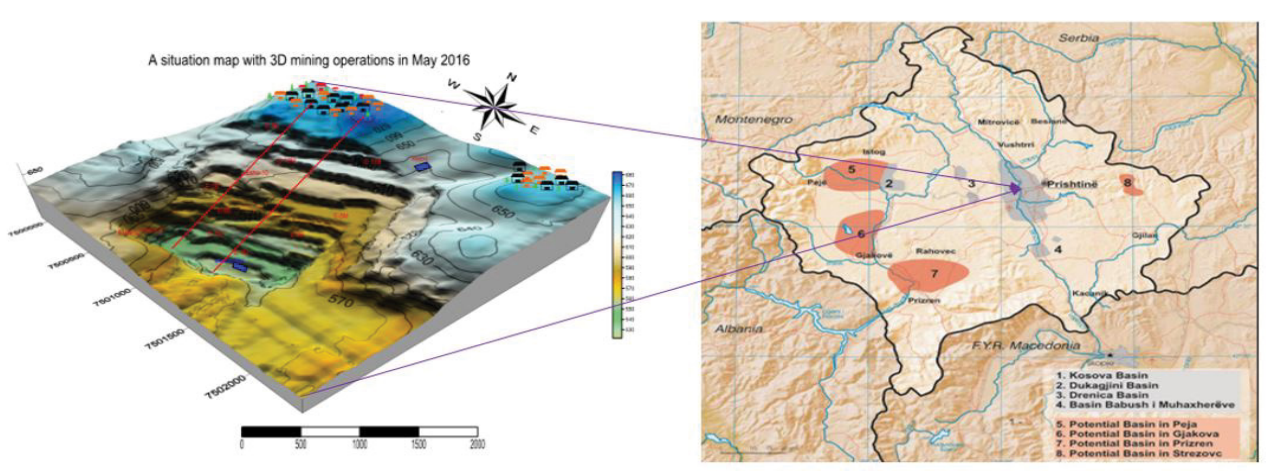

Figure 6: Map of the situation with the position of the coal deposits.

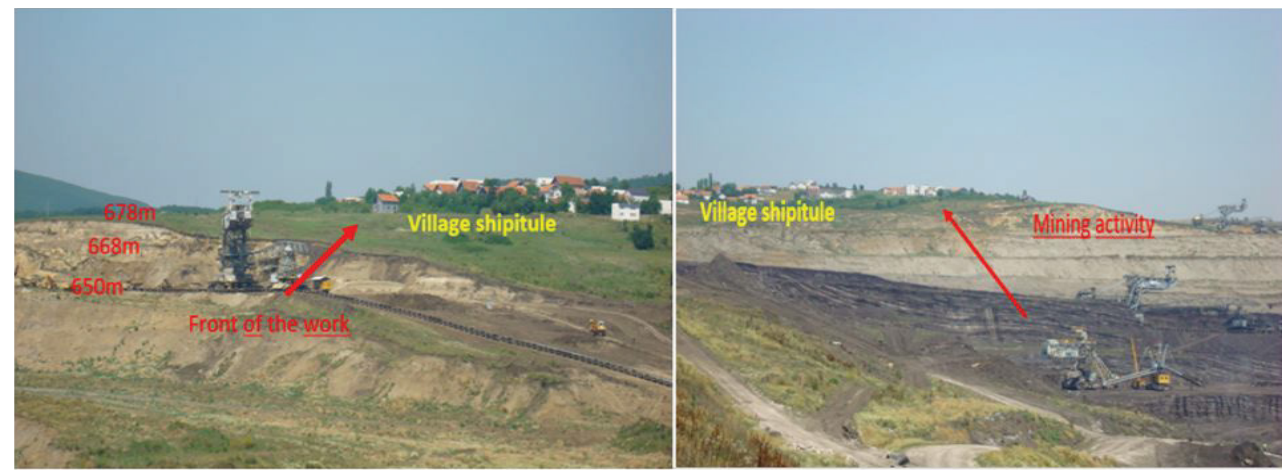

Figure 7: Mining activity in the direction of Shipitull village.

Gained results of physical parameters for each lithological layer of the slope; north and east are presented in Table 2 [3]. The obtained physical parameters for each lithological layer of the western slope are presented in Table 3 [3].

Statistical processing of hardness parameters: Geo-mechanic parameters or hardness parameters of geological layers have a considerable importance for defining the height and the angle in the surface mine. In order to obtain more accurate data, the determination of angle $\phi^{0}$ and cohesion $\mathrm{C}$ in the laboratory are done three methods [4-6] as in the Tables 4 and 5 [2].

a) Direct shear test

b) Triaxial tests

c) Ring shear test

The geo-mechanical parameters for the coal layer are taken from the existing documentation for the northern slope, eastern and western slope. Based on the fact that the coal layer has not encountered major changes over time, especially when it is covered with the overburden [7].

\section{Result}

By applying the equations $(1,2,3)$ and the tables mentioned above 4 and 5 , the final values of the angle $\phi$ and the cohesion $C$ for the calculation of the partial and general slopes are shown in Table 6 [1]. For coal exploitation with exploratory coal reserves of 15 million tones, preserving project geometry according to Figure 2 [2] and in parallel should be done the deployment of the Shipitull village in order to create the condition for mine expansion in southwest Sibovc. The final results of the mechanical parameters for the calculation of partial and general slopes for coal utilization for the country's economic development for the North, East and West slope are given in Table 6 [3]. The 3D overview of the slope [8] with the height $h=30 \mathrm{~m}$ and angle $\alpha=48^{\circ}$ (Figure 8) [1].

Calculations are done with two methods: Circular and polygonal methods according to authors shown in Figures 9 and 10 [8] and in Tables 7 and 8 . The geotechnical standard should be fulfilled with the safety factor as shown Table 1 .

\section{Discussion and Conclusion}

Based on the results of the geochemical analysis performed in the year (2015-2017) at the Inkos Institute's geo-mechanics laboratory, the mechanical parameters are extracted by using the three methods for extracting the angle $\phi^{\circ}$ and cohesion $\mathrm{C}$ as mentioned above: Trials Method, direct method and twisting methods. During the analysis we encountered changes in values therefore it was needed to make the statistical processing for all three tests by applying equations no. (1, 2, 3 ), for the real values, for the calculation of slopes, which are presented in Table 6.

On the basis of these results obtained from the statistical processing it is calculated the partial and general slopes in the surface mine according to the existing situation and the projected one. During the calculations, Slide v6 [9] and Geo5 [10] advanced software programs were used to verify the slope height and to find a possible solution for the exploitation of coal by not risking workers in the mine, technological equipment and at the same time not risking even the inhabitants of the village Shipitull. Two sliding mechanisms are used for calculations. The circular method present in clays and polygonal methods present in coal due to express tectonics. Based on the calculations, two software are 
Citation: Ahmeti H, Duraku V (2018) Endangering Residents in Shipitull Village by Landslide at the Surface Mining in South West Sibovc. J Civil Environ Eng 8: 315 doi: 10.4172/2165-784X.1000315

Page 5 of 8

\begin{tabular}{|c|c|c|c|c|c|c|c|c|}
\hline \multirow{2}{*}{ Lithological layers } & \multirow{2}{*}{ Geophysics parameters } & \multicolumn{7}{|c|}{ Statistical indicators } \\
\hline & & $\mathbf{X}_{\max }$ & $\mathbf{X}_{\text {average }}$ & $\mathbf{X}_{\min }$ & $\Sigma X i$ & $\sigma$ & $\mathbf{V}$ & $\mathbf{n}$ \\
\hline \multirow{3}{*}{ Yellow clay } & Volumetric weight & 19 & 17.3 & 15.5 & 1053.7 & 0.8 & 4.75 & 61 \\
\hline & Specific weight & 26.6 & 25.99 & 24.8 & 1429.3 & 0.4 & 1.43 & 55 \\
\hline & Natural moisture & 55.3 & 36.55 & 22.6 & 2229.5 & 6.1 & 16.6 & 61 \\
\hline \multirow{3}{*}{ Grey clay } & Volumetric weight & 21.7 & 17.67 & 15.2 & 2844.4 & 0.7 & 3.88 & 161 \\
\hline & Specific weight & 26.6 & 25.93 & 24.5 & 3604.8 & 0.4 & 1.65 & 139 \\
\hline & Natural moisture & 43.3 & 33.56 & 15.8 & 5403 & 3.6 & 10.3 & 161 \\
\hline \multirow{3}{*}{ Green clay } & Volumetric weight & 20.8 & 19.27 & 17.8 & 462.59 & 0.9 & 4.73 & 24 \\
\hline & Specific weight & 28.9 & 26.45 & 28.9 & 344.2 & 0.2 & 0.9 & 13 \\
\hline & Natural moisture & 32.8 & 25.01 & 12.7 & 600.18 & 4.6 & 18.5 & 24 \\
\hline
\end{tabular}

Table 2: The obtained results from statistical processing from physical parameters of the lithological layers of the slope; northern and eastern [3].

\begin{tabular}{|c|c|c|c|c|c|c|c|c|}
\hline \multirow{2}{*}{ Lithological layers } & \multirow{2}{*}{ Geophysics parameters } & \multicolumn{7}{|c|}{ Statistical indicators } \\
\hline & & $\mathbf{X}_{\max }$ & $\mathbf{X}_{\text {average }}$ & $\mathbf{X}_{\min }$ & $\Sigma X_{\mathbf{i}}$ & $\sigma$ & v & $\mathrm{Nr}$ \\
\hline \multirow{3}{*}{ Yellow clay } & Volumetric weight & 20.1 & 18.45 & 16 & 166.83 & 1.64 & 7.88 & 9 \\
\hline & Specific weight & 26.2 & 25.75 & 25.5 & 102.98 & 0.31 & 1.19 & 4 \\
\hline & Natural moisture & 45.4 & 24.01 & 15.6 & 216.05 & 10.1 & 41.9 & 9 \\
\hline \multirow{3}{*}{ Grey clay } & Volumetric weight & 21 & 19.03 & 16.7 & 285.43 & 1.44 & 7.57 & 15 \\
\hline & Specific weight & 26.6 & 25.94 & 24.8 & 311.25 & 0.54 & 2.1 & 12 \\
\hline & Natural moisture & 40.2 & 24.21 & 13.8 & 363.22 & 9.22 & 38.1 & 15 \\
\hline \multirow{3}{*}{ Green clay } & Volumetric weight & 20.1 & 19.5 & 16.3 & 1326.2 & 1.53 & 6.94 & 68 \\
\hline & Specific weight & 28.2 & 26.28 & 25.3 & 1235.3 & 0.59 & 2.24 & 47 \\
\hline & Natural moisture & 56.9 & 21.33 & 5.44 & 1450.3 & 9.36 & 39.2 & 68 \\
\hline
\end{tabular}

Table 3: The obtained results from statistical processing from physical parameters of the lithological layers of the western slope.

\begin{tabular}{|c|c|c|c|c|c|c|c|c|}
\hline \multirow{2}{*}{ Lithological layers } & \multirow{2}{*}{ Type of test } & \multicolumn{7}{|c|}{ Statistical indicators for geo-mechanical parameters } \\
\hline & & $\phi \max$ & $\phi \min$ & $\phi \mathrm{L}\left({ }^{\circ}\right)$ & Cmax & Cmin & CL & No. of tests \\
\hline \multirow{3}{*}{ Yellow clay } & Direct shear test & 19.26 & 7.22 & 12.5 & 22 & 0 & 6.28 & 46 \\
\hline & Triaxial test & 23.45 & 6.47 & 16.3 & 30 & 2 & 14.3 & 27 \\
\hline & Ring shear test & 16.35 & 4.44 & 9.72 & 12 & 0 & 5.41 & 23 \\
\hline \multirow{3}{*}{ Grey clay } & Direct shear test & 22.48 & 5.7 & 13.38 & 50 & 0 & 9.17 & 119 \\
\hline & Triaxial test & 20 & 8.18 & 14.59 & 60 & 0 & 19.6 & 55 \\
\hline & Ring shear test & 17.13 & 4.58 & 10.58 & 18 & 0 & 5.95 & 25 \\
\hline
\end{tabular}

Table 4: Statistical analysis of hardness parameter for the northern and eastern slope with three methods [3].

\begin{tabular}{|c|c|c|c|c|c|c|c|c|}
\hline \multirow{2}{*}{ Lithological layers } & \multirow{2}{*}{ Type of test } & \multicolumn{7}{|c|}{ Statistical indicators for geo-mechanical parameters } \\
\hline & & $\phi \max$ & $\phi \min$ & $\phi \mathrm{L}\left({ }^{\circ}\right)$ & Cmax & Cmin & CL & No. of tests \\
\hline \multirow{3}{*}{ Yellow clay } & Direct shear test & 17.6 & 12 & 15.67 & 6 & 0 & 3.67 & 3 \\
\hline & Triaxial test & 22.1 & 17 & 19.86 & 23 & 7 & 14 & 4 \\
\hline & Ring shear test & 15.1 & 9.2 & 13.28 & 7 & 0 & 4.64 & 11 \\
\hline \multirow{3}{*}{ Grey clay } & Direct shear test & 16.7 & 9.5 & 13.05 & 18 & 0 & 8 & 11 \\
\hline & Triaxial test & 28.37 & 13.37 & 19.2 & 21 & 10 & 14.8 & 8 \\
\hline & Ring shear test & 16.5 & 12 & 14.03 & 12 & 0 & 5.38 & 8 \\
\hline \multirow{3}{*}{ Green Clay } & Direct shear test & 20.1 & 7.6 & 13.86 & 23 & 0 & 6.46 & 49 \\
\hline & Triaxial test & 28.56 & 10 & 19.41 & 33 & 8.34 & 18.5 & 34 \\
\hline & Ring shear test & 21.1 & 8.18 & 16.45 & 18 & 1 & 7.53 & 40 \\
\hline
\end{tabular}

Table 5: Statistical processing of the western slope hardness parameters for the three [3].

\begin{tabular}{|c|c|c|c|}
\hline \multirow{2}{*}{ Lithological layers } & \multicolumn{3}{|c|}{ Physic-mechanic parameters } \\
\hline & $\phi\left({ }^{\circ}\right)$ & $\phi\left({ }^{\circ}\right)$ & C \\
\hline Yellow clay & 12.6 & 7.6 & 17.4 \\
\hline Grey clay & 13.3 & 11.5 & 17.67 \\
\hline Coal layer & 30 & 25 & 11.4 \\
\hline Green clay & 15.9 & 11.4 & 19.27 \\
\hline
\end{tabular}

Table 6: Geo-mechanical parameters for calculation [3].

used as comparative methods where it is noted that the security factor is smaller than Fs $<1$ the results are presented in Tables 7-9.

As for the detected coal reserves of 15 million tones are presented according to the profiles in Figures 2 and 3 that are divided according to available colors of 6.8 million tons of coal by preserving the safety factor Fs $>1.2$ based on geotechnical calculations. 
Citation: Ahmeti H, Duraku V (2018) Endangering Residents in Shipitull Village by Landslide at the Surface Mining in South West Sibovc. J Civil Environ Eng 8: 315 doi: 10.4172/2165-784X.1000315

Page 6 of 8

\begin{tabular}{|c|c|c|c|}
\hline Methods & Height $h(m)$ & Angle $\alpha^{\circ}$ & $\begin{array}{l}\text { Security factor (Fs)- circular } \\
\text { method }\end{array}$ \\
\hline Bishop-it & $30 \mathrm{~m}$ & $48^{\circ}$ & $F s=0.525$ \\
\hline Janbu & $30 \mathrm{~m}$ & $48^{\circ}$ & $F s=0.524$ \\
\hline Spancer & $30 \mathrm{~m}$ & $48^{\circ}$ & $F s=0.521$ \\
\hline Gorps of engineers\#1 & $30 \mathrm{~m}$ & $48^{\circ}$ & $F s=0.530$ \\
\hline Gorps of engineers\#2 & $30 \mathrm{~m}$ & $48^{\circ}$ & $F s=0.532$ \\
\hline Low-Karafiath & $30 \mathrm{~m}$ & $48^{\circ}$ & $\mathrm{Fs}=0.527$ \\
\hline GLE/Morgenstern-Price & $30 \mathrm{~m}$ & $48^{\circ}$ & $F s=0.520$ \\
\hline
\end{tabular}

Table 7: Calculation of the partial slope with software Silde V6 [9].

\begin{tabular}{|c|c|c|}
\hline Methods & Height $\mathbf{h}(\mathbf{m})$ & Angle $^{\circ}$ \\
\hline Janbu & $30 \mathrm{~m}$ & $48^{\circ}$ \\
\hline Spencer & $30 \mathrm{~m}$ & $48^{\circ}$ \\
\hline Sarma & $30 \mathrm{~m}$ & $48^{\circ}$ \\
\hline Morgenstem-Price & $30 \mathrm{~m}$ & Fs $^{\circ}=0.54$ \\
\hline
\end{tabular}

Table 8: Calculation of partial slope with the software Geo5 [10].

\begin{tabular}{|c|c|c|c|}
\hline Methods & Height $\mathrm{h}(\mathrm{m})$ & Angle $\alpha^{\circ}$ & Security factor (Fs)- circular shape \\
\hline Bishop-it & 10 & $30^{\circ}$ & $\mathrm{Fs}=1.073$ \\
\hline Janbu & 10 & $30^{\circ}$ & $\mathrm{Fs}=1.046$ \\
\hline Spancer & 10 & $30^{\circ}$ & $\mathrm{Fs}=1.069$ \\
\hline Gorps of Engineers\#1 & 10 & $30^{\circ}$ & $\mathrm{Fs}=1.093$ \\
\hline Gorps of Engineers\#2 & 10 & $30^{\circ}$ & $\mathrm{Fs}=1.107$ \\
\hline Low-Karafiath & 10 & $30^{\circ}$ & $\mathrm{Fs}=1.083$ \\
\hline GLE/Morgenstern-Price & 10 & $30^{\circ}$ & $\mathrm{Fs}=1.071$ \\
\hline
\end{tabular}

Table 9: Calculation of partial slope in the front work Geo5 Fine [10].

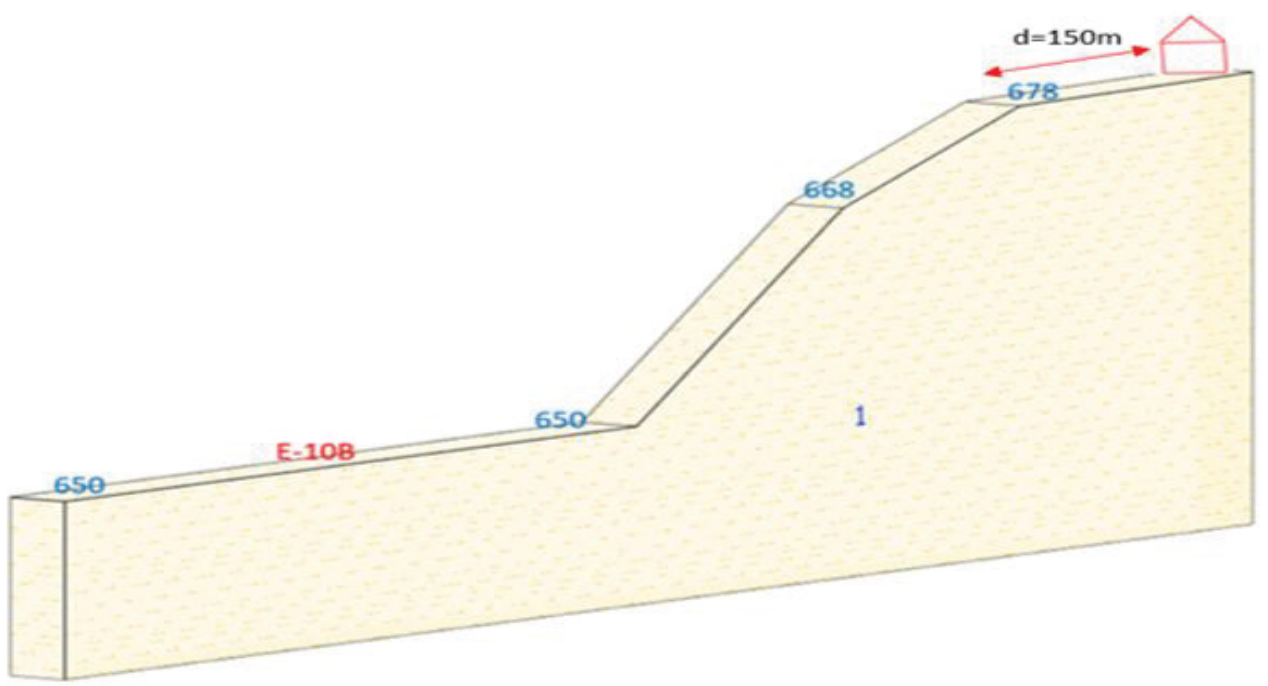

Figure 8: The 3D overview of the slope with the height $h=30 \mathrm{~m}$ and angle $\alpha=48^{\circ}$.

\section{Recommendations}

The detected coal reserves according to the above-mentioned profiles in Figure 2, 15 million tons of coal at the moment cannot be used for the cause of the security factor. Until technological conditions are created on the advancements of the front work for the removal of the overburden cover and making the favorable condition to work towards the Shipitullë village.

Coal reserves of 15 million tones can only be used for 6.8 million tons of coal with the $\alpha=13^{\circ}$ angle as shown in Figure 6, while remaining reserves of 6.2 million tons of coal can be used later on. For calculations, the geo-mechanical parameters are used to derive statistical processing according to heading no. 3.5. During the calculations two Slide V6 and Geo5 software were used as comparative methods by the authors for the safety factor Fs $\geq 1.3$ according to Figures 11 and 12 and Tables 10 and 11.

After the displacement of the inhabitants of the village Shipitull is done, then technological conditions are created for utilizing the remaining reserves of 6.2 million tons of coal by advancing towards the north, maintaining the safety factor and the general angle in the wasteland $\alpha=10^{\circ}$ and the general angle in coal $\alpha=18^{\circ}$ (Figure 2). According to the design situation with the safety factor and according to the geotechnical criteria and standards set out in Table 1 . 


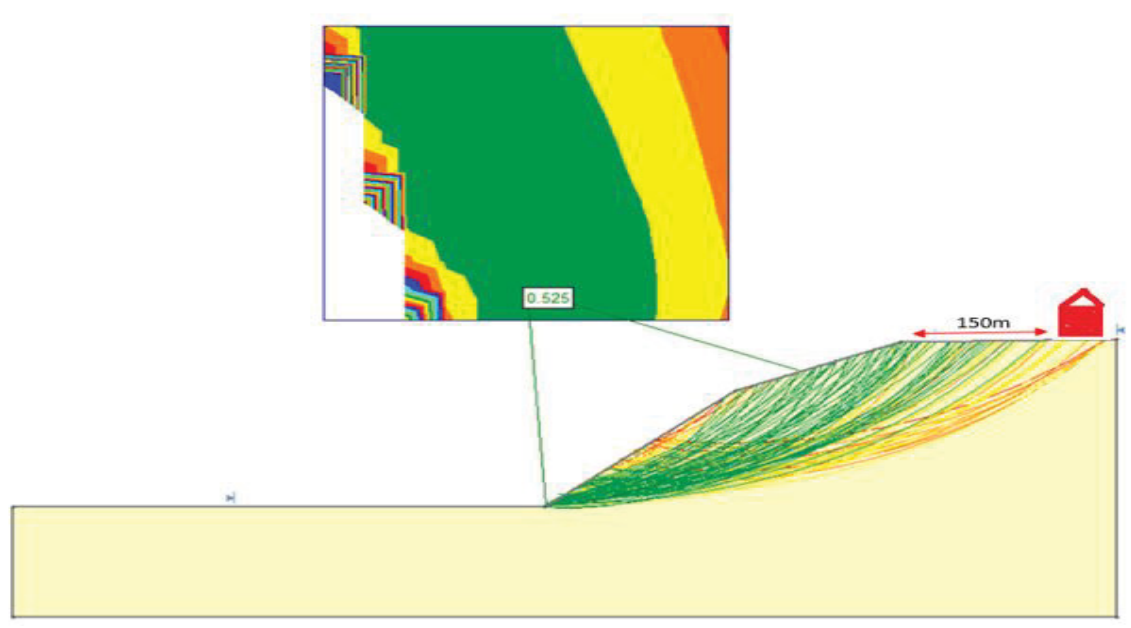

Figure 9: Calculation of the slope in the front work in the distance $150 \mathrm{~m}$ away from houses.

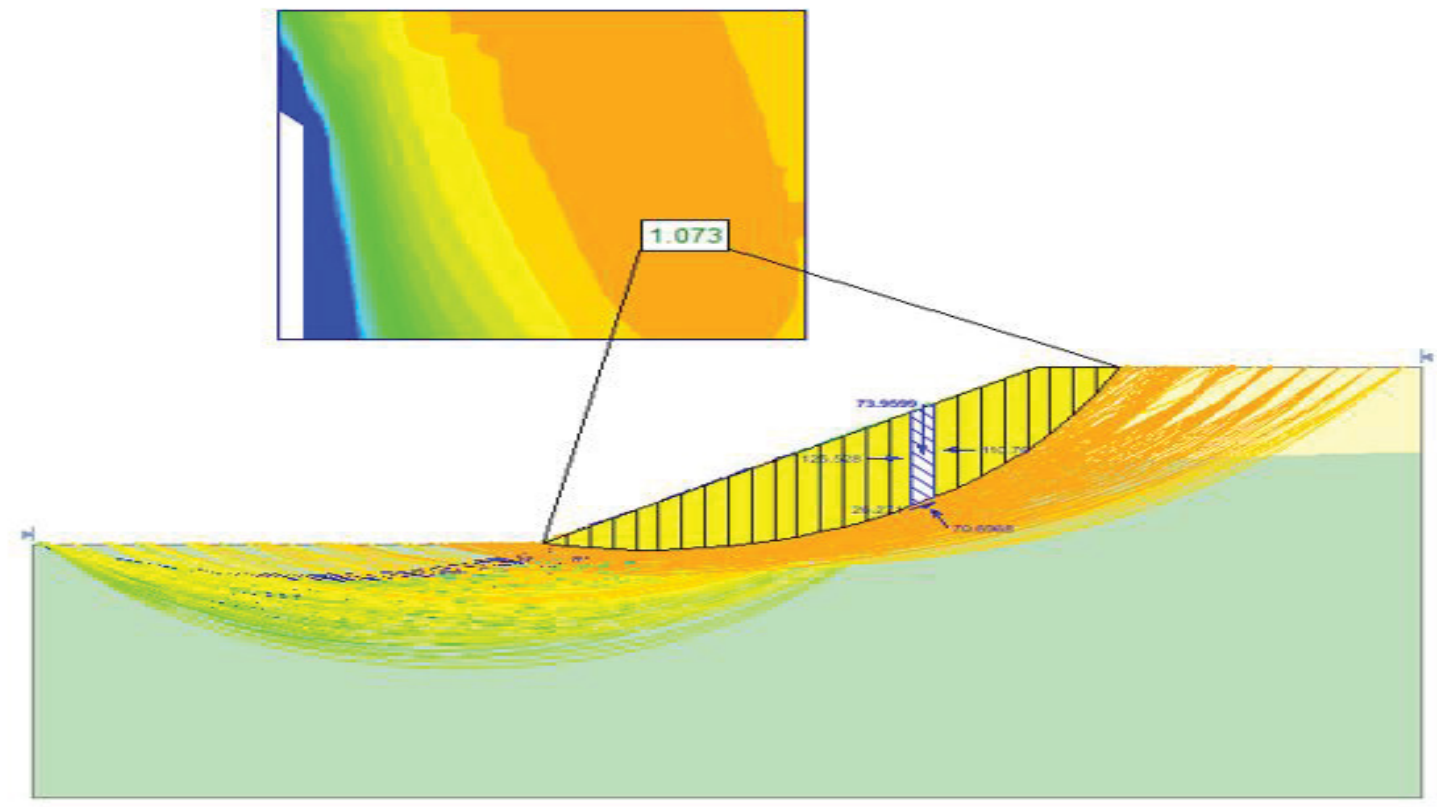

Figure 10: Calculation of partial slope in the front work Slide V6.

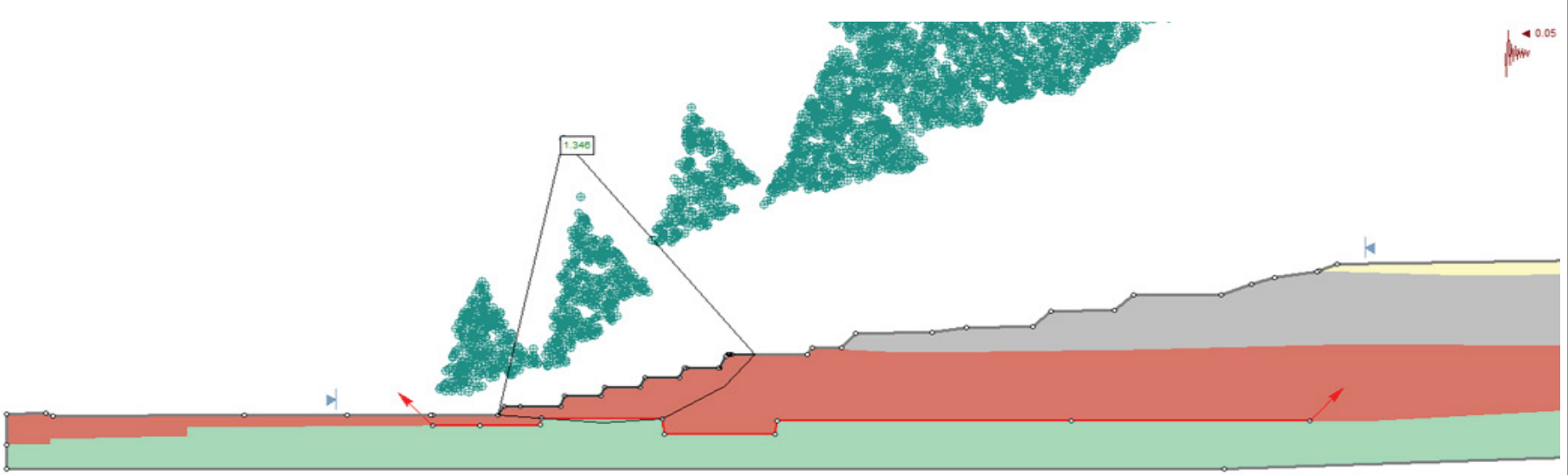

Figure 11: Calculation of the general slope in coal with height $h=50 \mathrm{~m}$ angle $\alpha=13^{\circ}$ with usable reserves 6.8 million tons. 


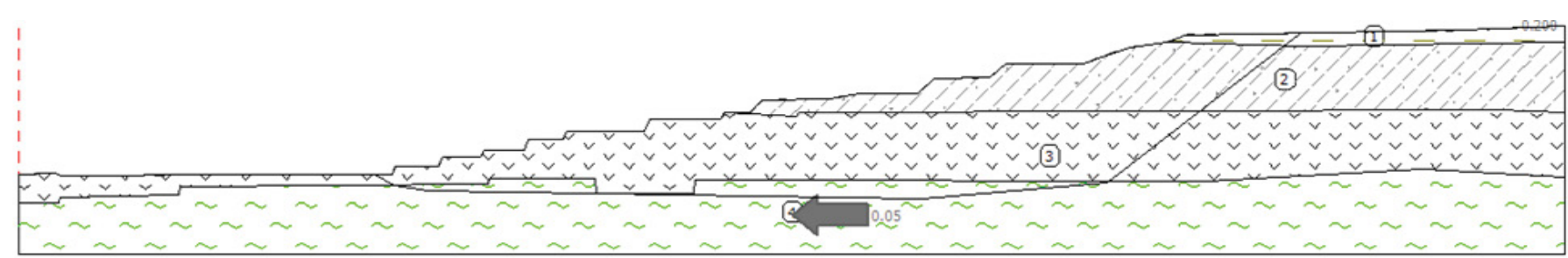

Figure 12: Comparable method of calculating the height $h=55 \mathrm{~m}$ angle $\alpha=13^{\circ}$ with useable reserves of 6.8 million tons analysed with the software Geo5.

\begin{tabular}{|c|c|c|c|}
\hline Methods & Height $h(m)$ & Angle $\alpha^{\circ}$ & Security factor (Fs)- polygonal method \\
\hline Janbu & $55 \mathrm{~m}$ & $13^{\circ}$ & $F s=2.27$ \\
\hline Spancer & $55 \mathrm{~m}$ & $13^{\circ}$ & $F s=1.35$ \\
\hline Gorps of engineers\#1 & $55 \mathrm{~m}$ & $13^{\circ}$ & $F s=1.35$ \\
\hline Gorps of engineers\#2 & $55 \mathrm{~m}$ & $13^{\circ}$ & $F s=1.30$ \\
\hline Low-Karafiath & $55 \mathrm{~m}$ & $13^{\circ}$ & $F s=1.32$ \\
\hline GLE/Morgenstern-Price & $55 \mathrm{~m}$ & $13^{\circ}$ & $F s=1.34$ \\
\hline
\end{tabular}

Table 10: Calculation of the general slope in coal in the height $h=55 \mathrm{~m}$ angle $\alpha=13^{\circ}$ with useable reserves of 6.8 million tons [1,2].

\begin{tabular}{|c|c|c|c|}
\hline Methods & Height $\mathbf{h}(\mathbf{m})$ & Angle $\boldsymbol{\alpha}^{\circ}$ & Security factor (Fs)- polygonal shape \\
\hline Janbu & $55 \mathrm{~m}$ & $13^{\circ}$ & $\mathrm{Fs}^{\circ}=1.28$ \\
\hline Spencer & $55 \mathrm{~m}$ & $13^{\circ}$ & $\mathrm{Fs}=1.31$ \\
\hline Sarma & $55 \mathrm{~m}$ & $13^{\circ}$ & $\mathrm{Fs}=1.33$ \\
\hline Morgenstem-Price & $55 \mathrm{~m}$ & $13^{\circ}$ & $\mathrm{Fs}=1.28$ \\
\hline Shahunyants & $55 \mathrm{~m}$ & $13^{\circ}$ & $\mathrm{Fs}=1.25$ \\
\hline
\end{tabular}

Table 11: Comparable methods on calculating the general slope in coal with height $h=55 \mathrm{~m}$ angle $\alpha=13^{\circ}$ with useable reserves of $6.8 \mathrm{million}$ ton $[1,2]$.

\section{References}

1. Ahmeti $\mathrm{H}$ (2017) Calculation of geological-geomechanical profiles- KastriotPrishtina 2: 1.

2. Krasniqi A, Kadru G, Ahmeti H (2017) Geological-geo-mechanical elaboration at the surface mine in southwestern Sibovc. Institute INKOS- Kastriot Prishtina.

3. Ahmeti H (2017) Statistical processing of physical-mechanical parametersKastriot-Prishtina.

4. Abramson LW, Lee TS, Sharma S, Boyce GM (2002) Slope Stability and Stabilization Methods. $2^{\text {nd }}$ edition John Wiley and Sons 2: 1.
5. Sarma SK (1973) Stability analysis of embankments and slopes. Géotechnique 23: $423-433$.

6. Sarma SK (1979) Stability analysis of embankments and slopes. J Geotech Geoenviron-ASCE 105: 1511-1524.

7. Jibson RW, Rathje EM, Jibson MW, Lee YW (2013) SLAMMER-Seismic Landslide Movement Modeled using Earthquake Records: US Geological Survey.

8. Golden software surfer 14 .

9. Software Slide V6.

10. Geotechnical software Fine GEO5 (2016). 